\title{
Future snow? A spatial-probabilistic assessment of the extraordinarily low snowpacks of 2014 and 2015 in the Oregon Cascades
}

\author{
Eric A. Sproles ${ }^{1,2}$, Travis R. Roth ${ }^{2}$, and Anne W. Nolin ${ }^{2}$ \\ ${ }^{1}$ Centro de Estudios Avanzados en Zonas Áridas, Universidad de La Serena, Raul Bitran 1305, La Serena, Chile \\ ${ }^{2}$ College of College of Earth, Ocean, and Atmospheric Sciences, Oregon State University, 104 CEOAS Admin Bldg, \\ Corvallis, OR 97331-5503, USA
}

Correspondence to: Eric A. Sproles (eric.sproles@gmail.com)

Received: 11 March 2016 - Published in The Cryosphere Discuss.: 21 March 2016

Revised: 10 November 2016 - Accepted: 15 November 2016 - Published: 1 February 2017

\begin{abstract}
In the Pacific Northwest, USA, the extraordinarily low snowpacks of winters 2013-2014 and 20142015 stressed regional water resources and the socialenvironmental system. We introduce two new approaches to better understand how seasonal snow water storage during these two winters would compare to snow water storage under warmer climate conditions. The first approach calculates a spatial-probabilistic metric representing the likelihood that the snow water storage of 2013-2014 and 2014-2015 would occur under $+2{ }^{\circ} \mathrm{C}$ perturbed climate conditions. We computed snow water storage (basin-wide and across elevations) and the ratio of snow water equivalent to cumulative precipitation (across elevations) for the McKenzie River basin $\left(3041 \mathrm{~km}^{2}\right)$, a major tributary to the Willamette River in Oregon, USA. We applied these computations to calculate the occurrence probability for similarly low snow water storage under climate warming. Results suggest that, relative to $+2{ }^{\circ} \mathrm{C}$ conditions, basin-wide snow water storage during winter 2013-2014 would be above average, while that of winter 2014-2015 would be far below average. Snow water storage on 1 April corresponds to a 42\% (2013-2014) and $92 \%$ (2014-2015) probability of being met or exceeded in any given year. The second approach introduces the concept of snow analogs to improve the anticipatory capacity of climate change impacts on snow-derived water resources. The use of a spatial-probabilistic approach and snow analogs provide new methods of assessing basin-wide snow water storage in a non-stationary climate and are readily applicable in other snow-dominated watersheds.
\end{abstract}

\section{Introduction}

In the Pacific Northwest (PNW), USA, mountain snowpacks during the winters of 2013-2014 and 2014-2015 were at or near record lows and well below $50 \%$ of the historic median value (Mote et al., 2016; National Resource Conservation Service, 2014, 2015b). For several decades the Natural Resources Conservation Service (NRCS) Snowpack Telemetry (SNOTEL) network has provided measurements of snow water equivalent (SWE; the amount of water contained within the snowpack) and meteorological data. These station-based measurements have historically served as a proxy for basinwide snow storage and provide an effective SWE index for estimating streamflow; however under a shifting climate these statistical relationships have also changed (Montoya et al., 2014). The PNW's extremely low snowpacks and subsequent snow water storage of 2013-2014 and 2014-2015 highlight the limitations of location-specific measurements in a shifting climate.

On 1 March 2015, $47 \%$ of snow monitoring sites in the Willamette River basin (WRB, $29730 \mathrm{~km}^{2}$, Fig. 1) registered zero SWE, while snow was still present at higher elevations. The absence of snow during the winter of 2014-2015 stands in contrast to cumulative winter precipitation, which was at $83 \%$ of normal $(778 \mathrm{~mm})$ for November-February (derived from PRISM (Parameter-elevation Relationships on Independent Slopes Model) data (Daly et al., 2008). While the concurrent drought in California received substantial attention, the economic and environmental impacts in the PNW were also profound. These two extremely low snowpacks 


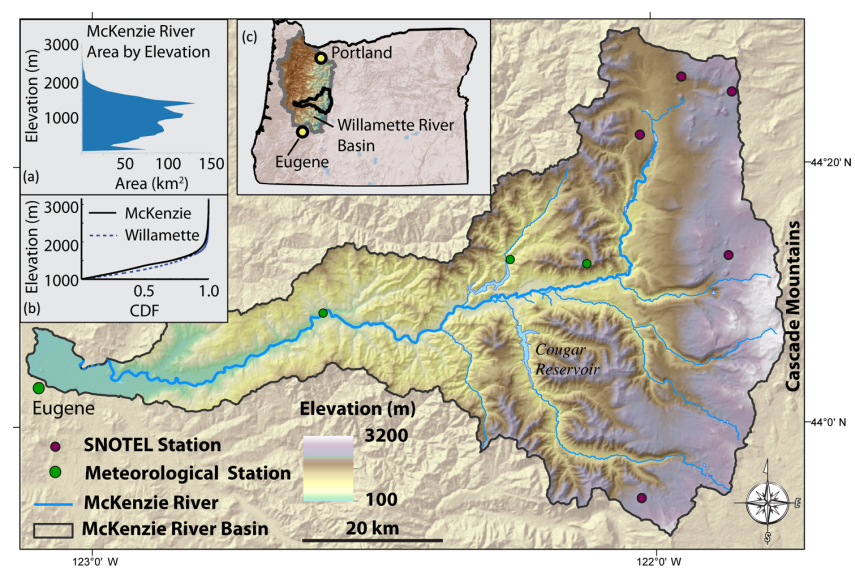

Figure 1. Context map of the McKenzie River basin and its geographic relationship to the Willamette River basin. The geographic locations of the SNOTEL and other meteorological stations used as model forcings show the altitudinal range of inputs. Inset (a) represents the area by elevation for the McKenzie River basin. Inset (b) presents the cumulative distribution functions (CDFs) for the elevation of the Willamette and McKenzie River basins for elevations above $1000 \mathrm{~m}$ and is separated into $50 \mathrm{~m}$ bins.

in the PNW led to ski area closures, recreation restrictions, municipal water limitations, severe wildfires, low streamflows, nearly dry reservoirs, harmful algal blooms, and high fish mortality (Associated Press, 2015; Morical, 2015; Oregon Department of Fish and Wildlife, 2015; Meunier, 2015; Wang et al., 2015). These types of externalities highlight the importance of mountain snow water storage and the implications of snow drought.

Mountain snow water storage in the western Oregon Cascades and across the western United States serves as vital inter-seasonal storage from cool, wet winters with low water demand to hot, dry summers when demand peaks (Oregon Water Supply \& Conservation Initiative, 2008; United States Army Corps of Engineers, 2001). The western Oregon Cascades form the eastern boundary of the WRB (Fig. 1), and abundant winter precipitation falling in these mountains (up to $3000 \mathrm{~mm} \mathrm{yr}^{-1}$ ) sustains the 13th-highest streamflow in the conterminous United States (Hulse et al., 2002). Even in such a wet place, snowmelt is critically important. Brooks et al. (2012) estimated that over $60-80 \%$ of summer base flow in the Willamette River derives from the snow zone at elevations over $1200 \mathrm{~m}$, though this elevational zone represents only $12 \%$ of the land area and $15.6 \%$ of the annual precipitation in the basin.

The McKenzie River basin (MRB, $3041 \mathrm{~km}^{2}$ ) is a major tributary to the WRB (Fig. 1) and is located in the main part of the Willamette's "at-risk" snow zone (Nolin and Daly, 2006). Snowmelt in the MRB is critical to meeting environmental and societal demands of the WRB, supplying almost $25 \%$ of the river's summer discharge at its confluence with the Columbia River near Portland, Oregon (Hulse et al., 2002), despite only occupying $10 \%$ of its area. The hypsometry of the MRB and WRB is visually similar (Fig. 1b) and statistically similar when tested using a two-parameter Kolmogorov-Smirnov test for sample distribution (Young, 1977).

The maritime snowpacks of the MRB, WRB, and the PNW are deep $(>1.5 \mathrm{~m})$ and relatively warm (Sturm et al., 1995), and SWE typically reaches its basin-wide maximum on approximately 1 April (Serreze et al., 1999; Stewart et al., 2004). Nolin and Daly (2006) identified snow in the WRB as climatologically "at-risk" since it typically accumulates at close to $0{ }^{\circ} \mathrm{C}$ and can convert to rainfall with just a slight increase in temperature. As a result of changes in circulation patterns and warmer temperatures, there have been declines on 1 April SWE in the PNW (Barnett et al., 2005; Kapnick and Hall, 2012; Luce and Holden, 2009; Mote, 2006; Mote et al., 2005; Service, 2004; Stoelinga et al., 2010), and peak streamflow has shifted to earlier in the year (Fritze et al., 2011; Stewart, 2009).

These shifts in streamflow highlight the challenges of using location-specific measurements of SWE for prediction in changing climate. While SNOTEL sites provide valuable and robust data, they typically occupy a limited elevation range that leads to an under-sampling of both the high-elevation snow zone and the lower-elevation rain-snow transition zone (Molotch and Bales, 2006; Montoya et al., 2014; Nolin, 2012). This limited range holds true in the MRB, where the mean elevation is $1424 \mathrm{~m}$ and the elevational range between the five stations is only $245 \mathrm{~m}$.

Elevational shifts in snowpack accumulation due to observed temperature increases make the past less representative of the future (Dozier, 2011; Milly et al., 2008). Additionally, patterns of snow accumulation and melt in the PNW vary as nonlinear functions of elevation, slope, aspect, and land cover (Tennant et al., 2015). Augmenting point-based measurements of SWE with metrics that effectively estimate snow water storage in a mountain landscape would include calculations for normal and extreme years across elevations and at the basin scale - especially under current climate trends (Dozier, 2011).

The dimensionless ratio of SWE to precipitation $(\mathrm{SWE}: P$ ) represents the proportion of snow water equivalent relative to cumulative precipitation (snowfall plus rainfall) over a specified time interval (Serreze et al., 1999). This ratio normalizes snow water storage by cumulative precipitation, emphasizing the impacts of temperature on snowpack accumulation and melt. When computed for 1 April, the time of year when maximum basin-scale SWE is considered to occur, this ratio can be an effective measure of the stages of accumulation and melt (Clow, 2010).

Understanding how relationships between snowpack, precipitation, and temperature will be expressed at the basin scale is particularly important in the maritime PNW. Physically based modeling studies of climate impacts in the PNW describe reduced snow water storage and earlier streamflow 
across the region (Elsner et al., 2010; Hamlet, 2011; Sproles et al., 2013). These deterministic approaches provide a range of outputs of past and future conditions. However these approaches stop short of an analog approach that links an individual year from the past, particularly a low snow year, to projected conditions.

Climate analogs serve as a useful device to examine potential impacts on societally relevant predictands (e.g., forest health, environmental flows, municipal water supply) and apply previous conditions to represent potential future conditions (Hallegatte et al., 2007; McLeman and Hunter, 2010; Ramírez-Villegas et al., 2011; Webb et al., 2013). For example, Ramírez-Villegas et al. (2011) developed analogs of climate and agricultural practices to identify prior climatic events that may provide insights into the impacts of future climate change in both time and space.

Incorporating an analog approach allows planners and managers to develop anticipatory capacity, the ability to better anticipate changing scenarios as needs and context change over time (Nelson et al., 2008; Rhodes and Ross, 2009). Using the extremely low snow water storage of 2014-2015 as an example, residents of the Willamette Valley raised concerns regarding the safety and taste of domestic drinking water during the summer months. These changes in water characteristics led public works departments to examine future strategies and equipment to mitigate future water quality concerns (Hall, 2015). From a hydrological perspective, this same analog approach is also used in describing streamflow and is most commonly framed using statistical metrics. For example, the spatial extent for a previous 100-year flood event serves as an analog of floodplain dynamics and provides anticipatory capacity for land use planners and water managers.

Based on the premise that future snow water storage conditions will resemble previous winters that were warm, Luce et al. (2014) developed spatial and temporal analogs of snow water storage sensitivity to temperature and precipitation across the western United States using point-based SNOTEL data. Similarly, Cooper et al. (2016) applied model-based analyses to compare the winters of 2014 and 2015 to projected future conditions using individual metrics of snowpack (snow disappearance date, date of peak SWE, and duration of snow cover) at SNOTEL locations in the Oregon Cascades. This approach is informative, even though pointbased analysis in projected warmer conditions may not represent basin-wide conditions (Dozier, 2011; Milly et al., 2008), specifically as the rain-snow transition shifts towards higher elevations (Nolin et al., 2012; Nolin and Daly, 2006).

Developing statistically valid analogs for snow water storage at the basin scale requires a spatially explicit, probabilistic approach that calculates the statistical likelihood of SWE across a topographically complex mountain basin. For example, the question, "What is the likelihood that the snow droughts of water years 2014 and 2015 will occur in the future?", can be addressed by developing statistical thresh- olds of SWE and SWE : $P$ with regards to time and location. This spatial-probabilistic approach develops upper or lower limits of predicted snow water storage conditions throughout a watershed. While probabilistic approaches are common to streamflow hydrology, spatial approaches to probabilistic questions are less common. A notable application of a spatially based, probabilistic approach was developed by Graf (1984). This research applied 107 years of channel migration records to calculate the probability of subsequent erosion in a given parcel, creating a probabilistic map of river movement. The map outlined the character of the river system that identified areas where channel migration was more likely to occur. Margulis et al. (2016) and Mote et al. (2016) characterized the extreme snow deficits of 2015 across the western United States, but they did not compare this snow drought to potentially warmer climatic conditions. Snow hydrology models can readily incorporate climate change projections (Adam et al., 2009; Sproles et al., 2013), and model outputs can be assessed using a spatial-probabilistic framework that explicitly accounts for elevation.

This research introduces a physically based, spatialprobabilistic modeling framework to compare the extraordinarily low snow winters of WYs 2014 and 2015 (WY: water year, defined as 1 October-30 September in the western United States) in the context of warmer climatic conditions. Our approach captures the spatial variability of mountain snow water storage under warmer temperatures across decades by simulating the variability of SWE and SWE : $P$ at the basin scale for $23 \mathrm{WYs}$ using $+2{ }^{\circ} \mathrm{C}$ conditions. These outputs are used to frame the snow water storage of WYs 2014 and 2015 in the context of future snow and snow analogs. This approach is intended to build anticipatory capacity for climate change impacts in the PNW through snow analogs. While limited to the McKenzie River basin (a wellstudied watershed that is characteristic for maritime snow in the WRB (Nolin and Daly, 2006), regional sensitivity to climate warming makes PNW snowpack and snow water storage, and those in similar maritime climates, acutely vulnerable to snow drought (Leibowitz et al., 2014; Nolin and Daly, 2006).

Specifically, we ask:

- How does snow water storage from WYs 2014 and 2015 compare to snow water storage under $+2{ }^{\circ} \mathrm{C}$ conditions?

- What is the probability that similar snowpacks and snow water storage will occur in the future?

- How does snow water storage during WYs 2014 and 2015 vary by elevation?

\section{Research methods}

Our approach applies a spatially distributed and physically based snow hydrology model to compute probabilities of 
SWE and SWE: $P$ for $23 \mathrm{WYs}$ under $+2{ }^{\circ} \mathrm{C}$ winter conditions. We then model snow water storage for WYs 2014 and 2015, which provide probabilistic context for snow water storage during these two winters. Below we provide details on the study area and specific methods used in this approach.

This study focuses on the McKenzie River basin. In addition to the MRB being a major tributary to the Willamette River, it has a well-developed network of meteorological stations associated with the HJ Andrews Long Term Ecological Research site, four SNOTEL stations, and four dams for flood control and hydropower; serves as the primary source of domestic water for approximately 200000 people; and is home to federally protected salmonids, amphibians, and mussels. The MRB is characterized by wet winters and dry summers, with average annual precipitation ranging from 1000 to $3000 \mathrm{~mm}$ that follows the elevation gradient (114-3147 m). Elevations between 1000 and $2000 \mathrm{~m}$ comprise $42 \%$ of the MRB's total area (Fig. 1a) and $93 \%$ of the total snow water storage in the MRB (Sproles et al., 2013). While elevations above $2000 \mathrm{~m}$ accumulate the most SWE per unit area, that zone comprises only $1 \%$ of total area and $6 \%$ of the total snow water storage for the MRB. In terms of volume, snow is the primary seasonal water storage mechanism in the MRB with historic mean basin-wide snow water storage (SWE $\times$ area; $1989-2009$ ) of $1.26 \mathrm{~km}^{3}$ on 1 April (Sproles et al., 2013), compared with total reservoir storage of $0.40 \mathrm{~km}^{3}$ (United States Army Corps of Engineers, 2016; United States Department of Agriculture, 2016). By comparison, groundwater storage for the MRB was estimated to be roughly $4 \mathrm{~km}^{3}$, with a mean transit time of 7 years (Jefferson et al., 2006).

Spatially distributed values of precipitation and SWE were computed using SnowModel (Liston and Elder, 2006a, b) for WYs 1989-2012. SnowModel is a spatially distributed, process-based model that computes temperature, precipitation, and the full winter season evolution of SWE including accumulation, canopy interception, wind redistribution, sublimation, evaporation, and melt. The model framework applied in this study is the same as applied in Sproles et al. (2013), with the addition of a multi-layer snowpack algorithm. Because the modeling framework is physically based and spatially distributed, perturbations to temperature inputs will propagate throughout the model, including absolute humidity and energy balance calculations; thus maintaining the dependencies between snowpack and temperature. WY 2005 was excluded due to prolonged regional temperature inversions that were not resolved in the model (Sproles et al., 2013).

Model input data were derived from SNOTEL and station data within the study area (six stations in total), nearly spanning the full elevation range of the MRB (Fig. 1; Sproles et al., 2013). The 23-year set of model forcing data includes winters with above-average, normal, and belowaverage snowpack; positive, negative, and neutral El NiñoSouthern Oscillation (ENSO) climate patterns; and cool and warm phases of the Pacific Decadal Oscillation (Brown and Kipfmueller, 2012). The model was run at a daily time step and $100 \mathrm{~m}$ grid resolution. In the calibration and validation phase, the model was first calibrated to temperature and precipitation to ensure that the model results were representative of these first-order inputs, with mean Nash-Sutcliffe efficiencies (Legates and McCabe, 1999; Nash and Sutcliffe, 1970) of 0.80 and 0.97 , respectively. The model was then calibrated for physical snowpack conditions (mean Nash-Sutcliffe efficiency of 0.83 for automated stations and 0.70 for field locations, and an overall spatial accuracy of $82 \%$ compared with Landsat fractional snow-covered area (fSCA) data). For a detailed description of the model structure, calibration, validation, and performance, please refer to Sproles et al. (2013).

Using the validated model, we increased temperatures by $+2{ }^{\circ} \mathrm{C}$ and re-ran the model over the same time frame and spatial domain. Projections for future precipitation in the WRB and the PNW are highly uncertain (Safeeq et al., 2016), and in the Oregon Cascades, temperature, not precipitation, dominates the accumulation and melt cycles of snowpack (Sproles, 2012; Sproles et al., 2013). Our delta increase in temperature is intended to be straightforward and avoids the uncertainties associated with projections for precipitation in the WRB and the PNW.

We extracted SWE and precipitation $(P)$ data, and computed 5-day averages for each centered on the first day of each month for January-June, for every year in the model run, and for each grid cell in the model domain. These 5-day mean values were used to minimize any effects from individual events (melt, snowfall) while still capturing the overall snow water storage characteristics at the beginning of the month.

Exceedance probability (EP) is a widely used hydrologic metric describing the statistical likelihood that a value of a given magnitude or greater will occur in a specified time period (e.g., annually) (Sadovský et al., 2012; Salas and Obeysekera, 2013). Expressed as a percentage, it is calculated as

$\mathrm{EP}=\left(\frac{m}{n+1}\right) \times 100$,

where $m$ is the rank of the data value (ranked from highest to lowest) and $n$ is the total number of data values (Dingman, 2002).

For example, $20 \%$ EP (a low annual exceedance probability) is the statistical likelihood that a value could be met or exceeded $20 \%$ of the time, or a one-in-five chance of occurring or being exceeded in any year. A $20 \%$ EP represents a relatively large value. A $90 \%$ EP (a high annual exceedance probability) describes the statistical likelihood of a measurement that would be met or exceeded in $90 \%$ of the time and represents a relatively low value. EP is commonly applied to point-based data such as a stream gage or SNOTEL station. However, because mountain snow water storage varies by elevation, slope, aspect, and land cover (Tennant et al., 2015), 
we expanded point-based EP calculations to the watershed scale to include normal and extreme years.

To accomplish a spatial perspective of exceedance probability, we applied 23 years of model output to compute the EP for the first of the month (January-June) based upon the 5-day averaged SWE and SWE : $P$ values for each grid cell in the model domain. The dimensions of the model domain is a grid of 759 rows $\times 1121$ columns. In order to sort each grid cell individually across the 23 data sets (years), the twodimensional data sets (759 rows $\times 1121$ columns) were decomposed into 23 one-dimensional vectors $(1 \times 850839)$ and then combined to create a $23 \times 850839$ matrix. The location information of each grid cell was retained for subsequent mapping and analysis. For each year, the 23 values in each row were sorted from highest to lowest. The $23 \times 850839$ data matrix was recomposed into 23 data matrices of dimension $759 \times 1121$, creating a corresponding spatial exceedance probability matrix. This was completed for each month (January-June).

To respond to the question, "How does snow water storage from WYs 2014 and 2015 compare to snow water storage under a warmer climate?," we modeled SWE and SWE: $P$ using SnowModel with meteorological forcing data from WYs 2014 and 2015 for the MRB, using the same stations as from our previously validated model runs. These model runs were validated using the same methods as described in Sproles et al. (2013). We then compared the snowpack metrics from WYs 2014 and 2015 with model output from the 23 water years under a $+2{ }^{\circ} \mathrm{C}$ climate scenario.

Elevation is the most important physiographic variable in determining SWE in this basin (Nolin, 2012), so we aggregated the data into $50 \mathrm{~m}$ elevation bands (Fig. 1a). In each of these bands we computed snow water storage $\left(\mathrm{km}^{3}\right)$ and mean SWE: $P(\mathrm{~m} / \mathrm{m})$. This allowed us to understand the variation of snowpack properties by elevation, their spatial probability of occurrence, and the statistical context for the extraordinary snowpacks of WYs 2014 and 2015.

An important point to bear in mind is that the EP values were computed using perturbed meteorological forcing data $\left(+2{ }^{\circ} \mathrm{C}\right)$, while values for WYs 2014 and 2015 were derived from unperturbed meteorological forcing data.

\section{Results}

For context, historically in the MRB, $62 \%$ of annual precipitation falls in the November-March (N-M) time period, as calculated from 30-year PRISM gridded climate normals of monthly precipitation (Daly et al., 2008). Within that period, December-February (DJF) are historically the coldest and wettest months (Daly et al., 2008). For N-M in WY 2014, precipitation was at $102 \%$ of the 30-year normal (calculated from PRISM data), and temperatures at SNOTEL stations in the MRB were $0.9^{\circ} \mathrm{C}$ warmer than normal (National Resource Conservation Service, 2015a). For the DJF
McKenzie River basin - precipitation, air temperature, and snow
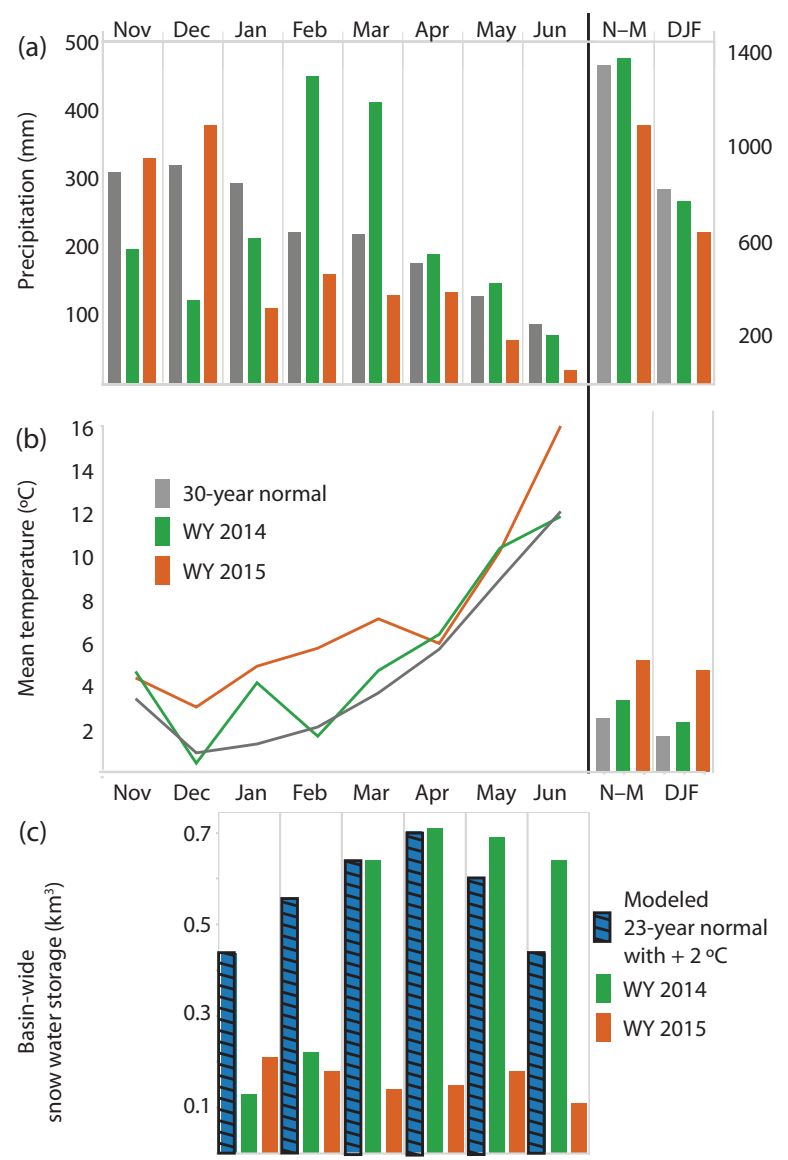

Figure 2. The total precipitation (a) and mean temperatures (b) for the McKenzie River basin for water years 2014 and 2015, as compared to the 30-year normal (from the PRISM data sets). The lower figure (c) represents basin-wide snow water storage for the McKenzie River basin for water years 2014 and 2015 and the normals $\left(+2{ }^{\circ} \mathrm{C}\right)$ calculated from the 23 years used in this study. The calculations for snowpack are 5-day averages centered on the first day of each month.

period, WY 2014 monthly precipitation was $96 \%$ of normal, and SNOTEL temperatures were $0.7{ }^{\circ} \mathrm{C}$ warmer than normal. During WY 2015, N-M precipitation was $81 \%$ of the 30-year average, but temperatures in the snow zone were $2.7^{\circ} \mathrm{C}$ warmer than average. For the DJF period of WY 2015, monthly precipitation was $78 \%$ of normal, and temperatures in the snow zone were $3.3^{\circ} \mathrm{C}$ warmer than normal (National Resource Conservation Service, 2015a). To provide historical context, Fig. $2 \mathrm{a}$ and $\mathrm{b}$ graphically present the 30 -year precipitation and temperature normals from the PRISM data sets as compared to WYs 2014 and 2015. Figure 2c presents modeled basin-wide snow water storage for WYs 2014 and 2015, as compared to the 23 -year mean from the $+2{ }^{\circ} \mathrm{C}$ snowpack simulations. 

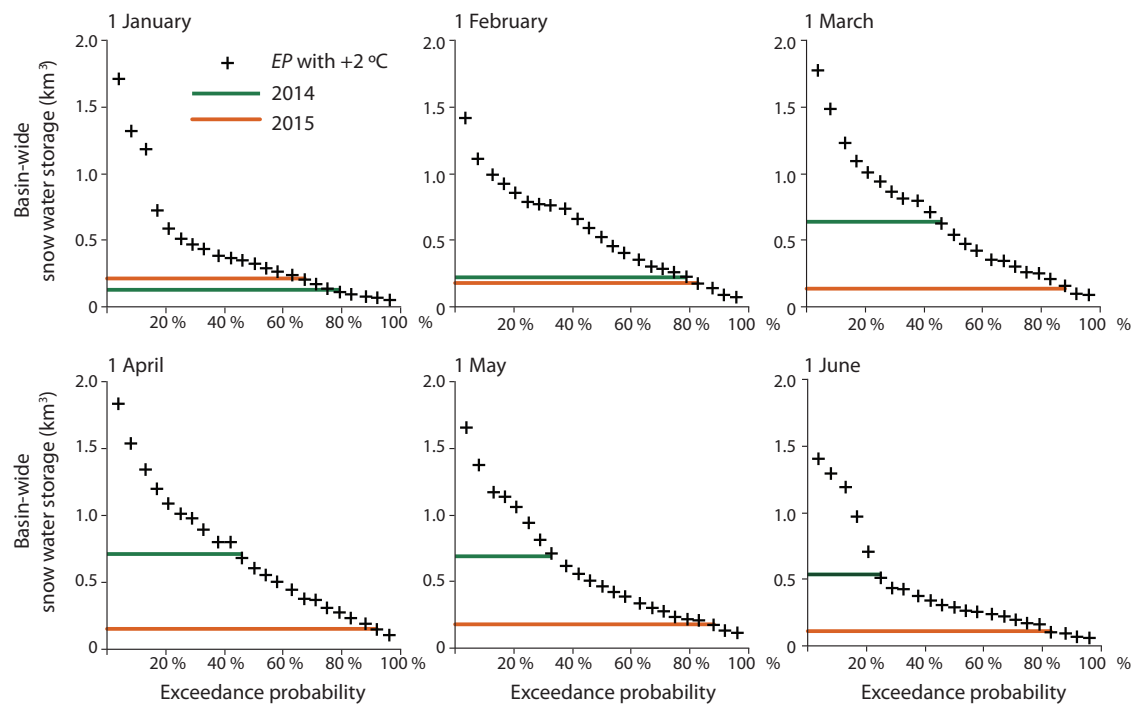

Figure 3. The exceedance probability of basin-wide snow water storage under $+2{ }^{\circ} \mathrm{C}$ conditions. During 2014 , snow water storage increased considerably in March to reach above-average conditions. The snowpack during the winter of 2015 was extremely low and never increased beyond $0.21 \mathrm{~km}^{3}$. The calculations are 5-day averages centered on the first day of each month.

A warmer-than-normal January 2014 limited snowpack accumulation during the early portion of the winter, and wetter-than-normal conditions in February 2014 accompanied by near normal mean temperatures increased basin-wide snow water storage to near-average/above-average snowpack conditions (as compared to a $+2{ }^{\circ} \mathrm{C}$ perturbation) for the remainder of the season (Fig. 2c). The warmer-than-normal conditions that persisted throughout WY 2015 greatly inhibited seasonal snowpack accumulation, despite above-average precipitation in March 2015 (Fig. 2c). For a more detailed long-term climate analysis please refer to Abatzoglou et al. (2014) and Mote et al. (2016).

\subsection{Snow water storage}

In the context of our exceedance probability framework, we see that the 1 April basin-wide snow water storage for WY 2014 falls between the 42 and $46 \%$ EP, meaning that WY 2014 snow water storage is slightly above average for a $+2{ }^{\circ} \mathrm{C}$ model perturbation (Figs. 2, 3, 4, 5a, c). Snowfall occurring after 1 April 2014 improved late-season snow water storage, corresponding to 33 and $25 \%$ EP for May and June, respectively (Figs. 3, 4). In WY 2015 basin-wide snow water storage was well below historical conditions, even when compared with $+2{ }^{\circ} \mathrm{C}$ conditions. 1 April snow water storage for WY 2015 corresponds to $92 \%$ EP (Figs. 3, 4, 5b, d). In that year, there was little late-spring snowfall, so, unlike WY 2014, basin-wide snow water storage did not increase (Fig. 3). WY 2015 was also notable in that peak snow water storage occurred in January and was only $0.21 \mathrm{~km}^{3}$, corresponding to $79 \%$ EP (Figs. 3, 4).
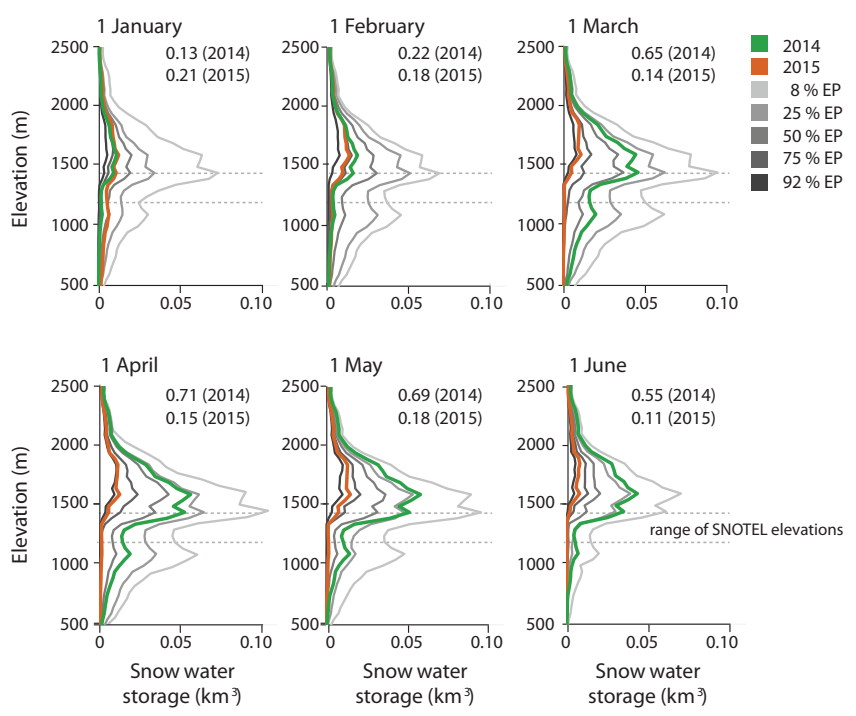

Figure 4. Volumetric snow water storage binned by $50 \mathrm{~m}$ elevation bands. The corresponding basin-wide snow water storage $\left(\mathrm{km}^{3}\right)$ for 2014 and 2015 is provided for each month. Larger snowpacks (lower exceedance probability) have considerable contributions between 1000 and $1300 \mathrm{~m}$. During 2014 and 2015, this elevation range had minimal snowpack, despite close-to-normal precipitation. Note that, on the vertical axes, snow water storage below 500 and above $2500 \mathrm{~m}$ is not included for visual clarity. These elevations contribute minimally to basin-wide snow water storage. The calculations are 5-day averages centered on the first day of each month.

Figure 4 shows the spatial exceedance probabilities for the $+2{ }^{\circ} \mathrm{C}$ model runs, aggregated into $50 \mathrm{~m}$ elevation increments (WY 2014, 42 \% EP; WY 2015, $92 \%$ EP). For most 

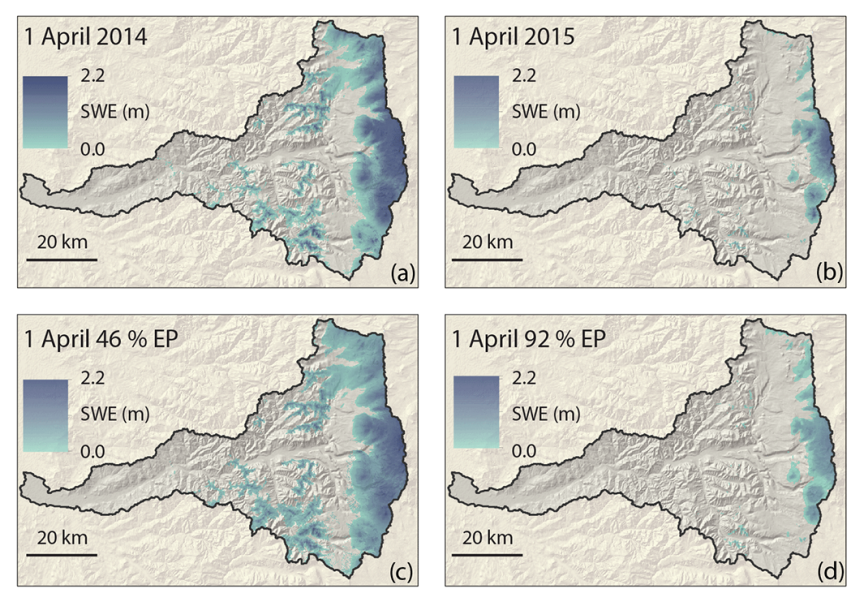

Figure 5. The spatial distribution of SWE on 1 April from water years 2014 and 2015 as compared to the corresponding EP. Both the distribution and magnitude of SWE are strikingly similar. The calculations are 5-day averages centered on the first day of each month.

years, the total amount of 1 April snow water storage is greatest within the elevation range of $1300-1800 \mathrm{~m}$. However, in WY 2015 this mid-elevation zone (1300-1800 m), representing $393 \mathrm{~km}^{2}$ (as calculated from the elevation data set), is essentially snow-free (Fig. 4). Snow water storage in this elevation range is critical for late-season runoff, as $1200 \mathrm{~m}$ represents the elevation threshold for summer baseflow contributions (Brooks et al., 2012). From a spatial perspective, Fig. 5 presents the distribution of SWE in the MRB in WYs 2014 and 2015 on 1 April, as compared to the 46 and $92 \%$ EP (as compared to a $+2{ }^{\circ} \mathrm{C}$ perturbation), respectively. These figures show that snow water storage is almost entirely limited to the upper portions of the basin and that the more spatially extensive mid-elevations where snow accumulates historically are snow-free. In other words, in WYs 2014 and 2015, the zone where snowmelt has historically contributed most to groundwater recharge (Jefferson et al., 2008; Tague and Grant, 2009) shifted to rain. Jefferson et al. (2008) showed that the recharge signal in the MRB varies spatially and temporally, and that the location of the rain-snow transition is the dominant control on recharge for at the watershed scale.

\subsection{SWE : $P$}

This elevation-dependent shift from rain to snow is evident in Fig. 6, where, at an elevation of $1200 \mathrm{~m}$, SWE: $P$ is below 0.06 for the period January to June in both WYs 2014 and 2015. This ratio does not exceed 0.20 until an elevation of $1500 \mathrm{~m}$ in WY 2014, which is still markedly lower than the long-term mean SWE: $P$ at the McKenzie SNOTEL site $(0.58,1454 \mathrm{~m})$. In WY 2015 this 0.20 threshold is not reached until an elevation of $1750 \mathrm{~m}$, approximately $300 \mathrm{~m}$ above the highest-elevation SNOTEL site in the MRB, and thus was not captured in the SNOTEL data. From Febru-
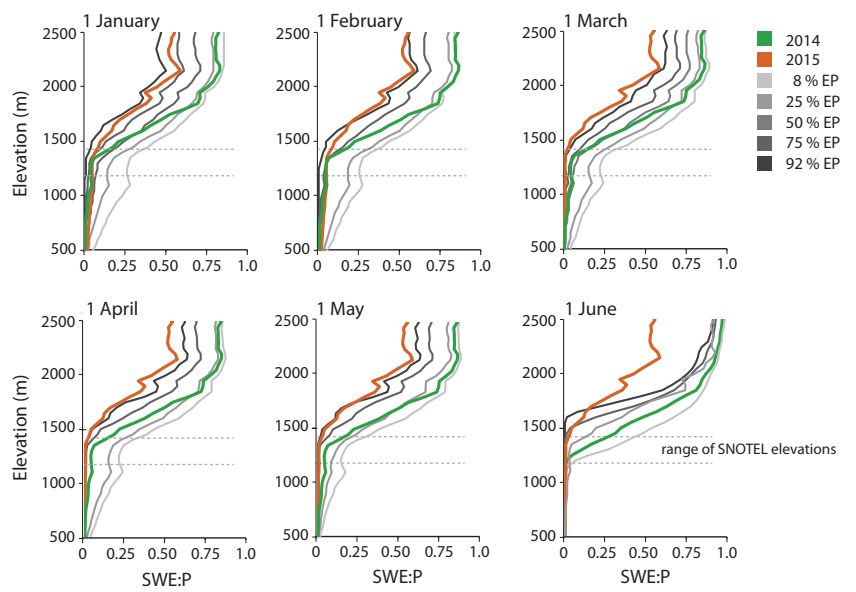

Figure 6. The ratio of SWE: $P$ binned by $50 \mathrm{~m}$ elevation bands. The relationship between elevation and SWE: $P$ is evident across all exceedance probabilities. Under $+2{ }^{\circ} \mathrm{C}$ simulations and in 2014 and 2015 , roughly $1500 \mathrm{~m}$ is the elevation at which SWE: $P$ begins to increase substantially along the horizontal axis. Note that, on the vertical axes, snow water storage below 500 and above $2500 \mathrm{~m}$ is not included for visual clarity. These elevations contribute minimally to basin-wide snow water storage. The calculations are 5-day averages centered on the first day of each month.

ary to May in WY 2014, SWE: $P$ increased due to lateseason storms that added snow water storage and remained above $50 \% \mathrm{EP}$ when compared with $+2{ }^{\circ} \mathrm{C}$ conditions. From February to May in WY 2015, SWE: $P$ never surpassed the 0.60 threshold and remained below $90 \% \mathrm{EP}$ when compared with $+2{ }^{\circ} \mathrm{C}$ conditions.

\section{Discussion and conclusion}

The winters of 2014 and 2015 had very low snowpacks across the Pacific Northwest due to higher-than-normal winter temperatures but average or near-average precipitation (Fig. 2, Mote et al., 2016; National Resource Conservation Service, 2014, 2015b), highlighting the sensitivity of the region's snowpack to increased temperature. In the MRB snow zone, mean temperatures $(\mathrm{N}-\mathrm{M})$ were $0.9^{\circ} \mathrm{C}$ above the 30-year normal in WY 2014, while in WY 2015 they were $2.7^{\circ} \mathrm{C}$ above normal. These low snow years persisted even under normal and slightly below normal N-M precipitation (WY 2014, 102\%; WY 2015, 81\%). The SWE: $P$ metric also identifies increased temperature, rather than reduced precipitation, as the primary reason for the diminished snow water storage of WYs 2014 and 2015, especially at mid-elevations. At $1500 \mathrm{~m}$, the April SWE: $P$ values for the 2 years are considerably different (Fig. 6; WY 2014, SWE : $P=0.22,60 \%$ EP; WY 2015, SWE : $P=0.04,95 \%$ $\mathrm{EP})$.

As such, these two winters' extraordinarily low snowpacks offer an analog perspective for projected future snow con- 
ditions in the MRB and, potentially, the Willamette River basin. WY 2014 serves as a snow analog for slightly warmer conditions $\left(+1{ }^{\circ} \mathrm{C}\right)$, with an EP between 42 and $46 \%$, while WY 2015 serves as a snow analog for conditions increasing beyond $2.5^{\circ} \mathrm{C}$ with an EP of around $92 \%$. The volumetric difference between the 2 years is considerable $\left(0.56 \mathrm{~km}^{3}\right)$, representing 1.4 times more than the total reservoir storage capacity of the MRB (United States Army Corps of Engineers, 2016; United States Department of Agriculture, 2016).

The SWE: $P$ metrics across elevation bands provide a simple yet telling description of precipitation phase (rainfall vs. snowfall) and the seasonal evolution of snow water storage (accumulation and ablation). The shifts from rain to snow seen in the modeled results highlight the limitations of a monitoring network that occupies a limited range. In the MRB, the SNOTEL stations occupy a mean elevation of $1424 \mathrm{~m}$, with a range of only $245 \mathrm{~m}$. During WYs 2014 and 2015, this limited range did not capture zones with maximum snow water volume and were essentially below the rain-snow transition (Figs. 4, 6). This same underrepresentation of snowpack was found throughout the greater WRB, with $47 \%$ of snow monitoring sites registering zero SWE while snow was still present at higher elevations on 1 March 2015.

As precipitation shifts from snow to rain, the SWE: $P$ metric can augment individual values of SWE and P to provide key information on shifts in water storage throughout the course of a winter and valuable insights to water resource managers in a non-stationary climate. For example, on 1 March, when basin-wide SWE is typically approaching its maximum, both years are essentially snow-free at $1200 \mathrm{~m}$. A low SWE: $P$ ratio in March under normal winter precipitation conditions could indicate peak streamflow has occurred or most likely would occur earlier in the year, which has important implications for water resource management in subsequent months.

Low snow water storage and shifts in streamflow negatively impact water quantity, water quality, hydropower operations, winter snow sports, and summer recreation. In WY 2015, record low snow water storage led to summer drought declarations, extreme fire danger, and modified hydropower operations in the MRB. The typical consistent flow of the groundwater-fed McKenzie River was at $63 \%$ of August-September median flow (United States Geological Survey, 2015). Hoodoo Ski Area, located at Santiam Pass, was open for only a few weekends in WY 2014, and in WY 2015 they suspended operations in mid-January, the shortest season in their 77-year history. In the adjacent Santiam River basin (north of the MRB), diminished snow water storage and less-than-anticipated spring rains in WY 2015 pushed the Detroit Reservoir (storage capacity $0.35 \mathrm{~km}^{3}$ ) to historically low levels. In May, harmful blue-green algae concentrations were above acceptable amounts by a factor of 7, and July reservoir levels were approximately $21 \mathrm{~m}$ below capacity. Concerns over the taste and safety of domestic drinking water in the Willamette Valley prompted municipal water managers to explore options for upgrading water treatment facilities.

At more broad timescales, the shift from snow to rain at mid-elevations could also potentially impact groundwater recharge. The rain-snow transition is the dominant control on recharge in the MRB and varies spatially and temporally (Jefferson et al., 2008). Because groundwater storage is large and transit times in the MRB are approximately 7 years (Jefferson et al., 2008), the full impacts of WYs 2014 and 2015 on ground and surface water resources are not yet known.

Water quality, energy production, and recreation externalities are not well represented in deterministic models but become challenging realities that the public faces in years with low snow. Intervention strategies can fail because they lack adequate information about the impacts of climate change and are not incorporated into deterministic physical models that play out at the human scale (Ramírez-Villegas et al., 2011). Transitioning from purely deterministic approaches (i.e., snow water storage is reduced by a certain percentage) to ones that link climate and snow conditions with real-world impacts provides a complementary perspective for mitigation and adaptation. Our analog approach combines projected climate impacts with the extremely low snow years of 2013-2014 and 2014-2015 for insights into improved management in shifting conditions. Such an analog approach allows planners and managers to develop adaptation and mitigation strategies that use the past to demonstrate what did or did not work under climate stress and help build a more informed understanding of ways to improve future planning efforts (Ramírez-Villegas et al., 2011).

Climate change impacts are often expressed in probabilistic terms (Randall et al., 2007), and so it is logically consistent to estimate snowpacks and snow water storage in this manner. This research does not assume that the probabilities presented here are based upon a precise representation of future conditions, nor that future climates will be $+2{ }^{\circ} \mathrm{C}$ warmer every winter. We present these results as a way to frame the likelihood of future basin-wide snow water storage in the context of our current understanding of climate change. These probabilistic insights are then used to identify WYs 2014 and 2015 as analog years for managers and decision makers. Snow water storage in WY 2014 would be slightly above average for $+2^{\circ} \mathrm{C}$ conditions, and snow water storage in WY 2015 would be very low for $+2{ }^{\circ} \mathrm{C}$ conditions, albeit not a record low. These analog years thus provide guidance for adaptation strategies to mitigate potential failures of existing management plans.

Our spatially explicit approach augments information from the existing SNOTEL network. While SNOTEL data continue to play a key role for seasonal streamflow forecasting under historic climatic conditions, these statistical relationships have been changing (Montoya et al., 2014). While providing modern scientific equipment, SNOTEL sites in the MRB occupy a limited range $(245 \mathrm{~m})$ at the mid- 
elevations and may not capture basin-wide snow water storage in warmer conditions. For example, in the MRB, all SNOTEL sites in the MRB were snow-free for most of February to March 2015 and were, therefore, incapable of providing predictive skill for water resource management. Our basin-scale probabilistic approach provides a more complete picture of water storage and captures the elevation variability absent in point-based measurements.

The winters of WYs 2014 and 2015 demonstrate a considerable departure from the stationary snow water storage conditions on which present-day management plans are based. With continued current warmer climates, the snow water storage conditions represented by these two winters are more likely to occur. In the meantime, the value of spatially explicit probabilistic calculations rests in the ability to better define the range of statistical outcomes of subsequent winters that are representative of basin-wide conditions. Framing the low snow water storage of WYs 2014 and 2015 as analogs of future snow provides insights into potential climate impacts and externalities on social and environmental systems. Together, probabilistic metrics and snow water storage analogs can help build capacity to better anticipate hydrologic changes in a warming climate.

\section{Data availability}

The data used in this article are available at doi:10.7267/N9V985ZN.

Acknowledgements. This research was funded in part by a NASA award entitled "New Metrics for Snow in a Warming World: Indicators for the National Climate Assessment" (proposal no. 14-INCA14-0089) and two awards from the National Science Foundation (Doctoral Dissertation Improvement, BCS-0903118; Water Sustainability and Climate, EAR-1039192). We gratefully acknowledge the modeling guidance of Glen Liston. The authors would also like to thank the associate editor, Ross Brown, and P. Mote and another anonymous reviewer for their insightful comments that significantly improved the quality of the manuscript.

Edited by: R. Brown

Reviewed by: P. Mote and one anonymous referee

\section{References}

Abatzoglou, J. T., Rupp, D. E., and Mote, P. W.: Seasonal climate variability and change in the Pacific Northwest of the United States, J. Climate, 27, 2125-2142, 2014.

Adam, J. C., Hamlet, A. F., and Lettenmaier, D. P.: Implications of global climate change for snowmelt hydrology in the twenty-first century, Hydrol. Process., 23, 962-972, doi:10.1002/hyp.7201, 2009.

Associated Press: Drought has city near Eugene imposing water restrictions, The Washington Times, available at: http://www.washingtontimes.com/news/2015/jul/29/drought, last access: 15 September 2016, 29 July 2015.

Barnett, T. P., Adam, J. C., and Lettenmaier, D. P.: Potential impacts of a warming climate on water availability in snow-dominated regions, Nature, 438, 303-309, doi:10.1038/nature04141, 2005.

Brooks, J. R., Wigington, P. J., Phillips, D. L., Comeleo, R., and Coulombe, R.: Willamette River Basin surface water isoscape $\left(\delta^{18} \mathrm{O}\right.$ and $\left.\delta^{2} \mathrm{H}\right)$ : temporal changes of source water within the river, Ecosphere, 3, 39, doi:10.1890/ES11-00338.1, 2012.

Brown, D. P. and Kipfmueller, K. F.: Pacific Climate Forcing of Multidecadal Springtime Minimum Temperature Variability in the Western United States, Ann. Assoc. Am. Geogr., 102, 521530, doi:10.1080/00045608.2011.627052, 2012.

Clow, D. W.: Changes in the timing of snowmelt and streamflow in Colorado: a response to recent warming, J. Climate, 23, 22932306, 2010.

Cooper, M. G., Nolin, A. W., and Safeeq, M.: Testing the recent snow drought as an analog for climate warming sensitivity of Cascades snowpacks, Environ. Res. Lett., 11, 84009, doi:10.1088/1748-9326/11/8/084009, 2016.

Daly, C., Halbleib, M., Smith, J. I., Gibson, W. P., Doggett, M. K., Taylor, G. H., Curtis, J., and Pasteris, P. P.: Physiographically sensitive mapping of climatological temperature and precipitation across the conterminous United States, Int. J. Climatol., 28, 2031-2064, 2008

Dingman, S. L.: Physical hydrology, Prentice Hall, Upper Saddle River, NJ, 2002.

Dozier, J.: Mountain hydrology, snow color, and the fourth paradigm, Eos T. Am. Geophys. Un. USA, 92, 373, doi:10.1029/2011EO430001, 2011.

Elsner, M. M., Cuo, L., Voisin, N., Deems, J. S., Hamlet, A. F., Vano, J. A., Mickelson, K. E. B., Lee, S.-Y., and Lettenmaier, D. P.: Implications of 21 st century climate change for the hydrology of Washington State, Climatic Change, 102, 225-260, 2010.

Fritze, H., Stewart, I. T., and Pebesma, E.: Shifts in Western North American Snowmelt Runoff Regimes for the Recent Warm Decades, J. Hydrometeorol., 12, 989-1006, doi:10.1175/2011jhm1360.1, 2011.

Hall, B.: Something in the water: Complaints about taste trickle in, Corvallis Gazette-Times, available at: http://www.gazettetimes.com/news/something-in, last access: 15 September 2016, 5 August 2015.

Hallegatte, S., Hourcade, J.-C., and Ambrosi, P.: Using climate analogues for assessing climate change economic impacts in urban areas, Climatic Change, 82, 47-60, 2007.

Hamlet, A. F.: Assessing water resources adaptive capacity to climate change impacts in the Pacific Northwest Region of North America, Hydrol. Earth Syst. Sci., 15, 1427-1443, doi:10.5194/hess-15-1427-2011, 2011.

Hulse, D., Gregory, S., and Baker, J. P. (Eds.): Willamette River Basin planning atlas: trajectories of environmental and ecological change, Oregon State University Press, 2002.

Jefferson, A., Grant, G., and Rose, T.: Influence of volcanic history on groundwater patterns on the west slope of the Oregon High Cascades, Water Resour. Res., 42, W12411, doi:10.1029/2005WR004812, 2006.

Jefferson, A., Nolin, A., Lewis, S., and Tague, C.: Hydrogeologic controls on streamflow sensitivity to climate variation, Hydrol. Process., 22, 4371-4385, doi:10.1002/hyp.7041, 2008. 
Kapnick, S. and Hall, A.: Causes of recent changes in western North American snowpack, Clim. Dynam., 38, 1885-1899, 2012.

Legates, D. R. and McCabe, G. J.: Evaluating the use of "goodness-of-fit" measures in hydrologic and hydroclimatic model validation, Water Resour. Res., 35, 233-241, doi:10.1029/1998WR900018, 1999.

Leibowitz, S. G., Comeleo, R. L., Wigington Jr., P. J., Weaver, C. P., Morefield, P. E., Sproles, E. A., and Ebersole, J. L.: Hydrologic landscape classification evaluates streamflow vulnerability to climate change in Oregon, USA, Hydrol. Earth Syst. Sci., 18, 33673392, doi:10.5194/hess-18-3367-2014, 2014.

Liston, G. E. and Elder, K.: A Distributed Snow-Evolution Modeling System (SnowModel), J. Hydrometeorol., 7, 1259-1276, doi:10.1175/JHM548.1, 2006a.

Liston, G. E. and Elder, K.: A Meteorological Distribution System for High-Resolution Terrestrial Modeling (MicroMet), J. Hydrometeorol., 7, 217-234, doi:10.1175/JHM486.1, 2006b.

Luce, C. H. and Holden, Z. A.: Declining annual streamflow distributions in the Pacific Northwest United States, 1948-2006, Geophys. Res. Lett., 36, L16401, doi:10.1029/2009GL039407, 2009.

Luce, C. H., Lopez-Burgos, V., and Holden, Z.: Sensitivity of snowpack storage to precipitation and temperature using spatial and temporal analog models, Water Resour. Res., 50, 9447-9462. 2014.

Margulis, S. A., Cortés, G., Girotto, M., Huning, L. S., Li, D., and Durand, M.: Characterizing the extreme 2015 snowpack deficit in the Sierra Nevada (USA) and the implications for drought recovery, Geophys. Res. Lett., 43, 6341-6349, 2016.

McLeman, R. A. and Hunter, L. M.: Migration in the context of vulnerability and adaptation to climate change: insights from analogues, Wiley Interdisciplinary Reviews: Climate Change, 1, 450-461, doi:10.1002/wcc.51, 2010.

Meunier, A.: Oregon's wildfire season is over for 2015, Forestry Department says, The Oregonian, available at: http://www.oregonlive.com/wildfires/index.ssf/2015/10/, last access: 15 September 2016, 25 October 2015.

Milly, P. C. D., Betancourt, J., Falkenmark, M., Hirsch, R. M., Kundzewicz, Z. W., Lettenmaier, D. P., and Stouffer, R. J.: Stationarity Is Dead: Whither Water Management?, Science, 319, 573-574, doi:10.1126/science.1151915, 2008.

Molotch, N. P. and Bales, R. C.: SNOTEL representativeness in the Rio Grande headwaters on the basis of physiographics and remotely sensed snow cover persistence, Hydrol. Process., 20, 723-739, 2006.

Montoya, E. L., Dozier, J., and Meiring, W.: Biases of April 1 snow water equivalent records in the Sierra Nevada and their associations with large-scale climate indices, Geophys. Res. Lett., 41, 5912-5918, 2014.

Morical, M.: Is Hoodoo done? Barely-there snow has Oregon ski areas wondering if season is over, The Bulletin, Bend, OR, available at: http://www.bendbulletin.com/outdoors/ 2854005-151/barely-there, last access: 15 September 2016, 11 February 2015.

Mote, P. W.: Climate-Driven Variability and Trends in Mountain Snowpack in Western North America, J. Climate, 19, 62096220, doi:10.1175/JCLI3971.1, 2006.

Mote, P. W., Hamlet, A. F., Clark, M. P., and Lettenmaier, D. P.: Declining Mountain Snowpack in Weatern North America, B. Am. Meteorol. Soc., 86, 39-49, doi:10.1175/BAMS-86-1-39, 2005.
Mote, P. W., Rupp, D. E., Li, S., Sharp, D. J., Otto, F., Uhe, P. F., Xiao, M., Lettenmaier, D. P., Cullen, H., and Allen, M. R.: Perspectives on the causes of exceptionally low 2015 snowpack in the western United States, Geophys. Res. Lett., 43, 10980 10988, doi:10.1002/2016GL069965, 2016.

Nash, J. E. and Sutcliffe, J. V: River flow forecasting through conceptual models part I: a discussion of principles, J. Hydrol., 10, 282-290, doi:10.1016/0022-1694(70)90255-6, 1970.

National Resource Conservation Service: Weekly Snowpack / Drought Monitor Update, Washington, D.C., 2014.

National Resource Conservation Service: NRCS SNOTEL data, edited by: United States Department of Agriculture, available at: https://www.nrcs.usda.gov/wps/portal/nrcs/main/or/snow/, last access: 9 September 2015a.

National Resource Conservation Service: Weekly Water and Climate Update, Washington, D.C., available at: http://www.wcc. nrcs.usda.gov/ftpref/support/drought/dmrpt-20150326.pdf, last access: 15 September 2016, 2015 b.

Nelson, N., Geltzer, A., and Hilgartner, S.: Introduction: the anticipatory state: making policy-relevant knowledge about the future, Science and Public Policy, 35, 546-550, doi:10.3152/030234208X370648, 2008.

Nolin, A. W.: Perspectives on Climate Change, Mountain Hydrology, and Water Resources in the Oregon Cascades, USA, Mt. Res. Dev., 32, S35-S46, doi:10.1659/mrd-journal-d-1100038.s1, 2012.

Nolin, A. W. and Daly, C.: Mapping "At Risk" Snow in the Pacific Northwest, J. Hydrometeorol., 7, 1164-1171, 2006.

Nolin, A. W., Sproles, E. A., and Brown, A.: Climate change impacts on snow and water resources in the Columbia, Willamette, and McKenzie River Basins, USA: A nested watershed study, in: Transboundary River Governance in the Face of Uncertainty: The Columbia River Treaty, edited by: Cosens, B., Oregon State University Press, Corvallis, OR, 2012.

Oregon Department of Fish and Wildlife (ODFW): Higher water temperatures primary cause of early spring Chinook mortality, ODFW Resources, News Releases, available at: http://www. dfw.state.or.us/news/2015/june/061815.asp, last access: 18 July 2016.

Oregon Water Supply \& Conservation Initiative (OWSCI): Southern Willamette Valley Municipal Water Providers (SWMWP), Final Report, 64 pp., 2008.

Ramírez-Villegas, J., Lau, C., Kohler, A. K., Jarvis, A., Arnell, N., Osborne, T., and Hooker, J.: Climate Analogues: Finding tomorrow's agriculture today, CGIAR Research Program on Climate Change, Agriculture and Food Security (CCAFS), Cali, Colombia, Working Paper No. 12, 42 pp., 2011.

Randall, D. A., Wood, R. A., Bony, S., Colman, R., Fichefet, T., Fyfe, J., Kattsov, V., Pitman, A., Shukla, J., Srinivasan, J., Stouffer, R. J., Sumi, A., and Taylor, K. E.: Climate Change 2007 The Physical Science Basis: Working Group I Contribution to the Fourth Assessment Report of the IPCC, edited by: Solomon, S., Qin, D., Manning, M., Chen, Z., Marquis, M., Averyt, K. B., Tignor, M., and Miller, H. L., Book, Cambridge University Press, Cambridge, United Kingdom and New York, NY, USA, 2007.

Rhodes, D. H. and Ross, A. M.: Anticipatory capacity: Leveraging model-based approaches to design systems for dynamic futures, in: 2nd Annual Conference on Model-based Systems, Haifa, Israel, 46-51, March 2009. 
Sadovský, Z., Faško, P., Mikulová, K., and Pecho, J.: Exceptional snowfalls and the assessment of accidental snow loads for structural design, Cold Reg. Sci. Technol., 72, 17-22, doi:10.1016/j.coldregions.2011.12.003, 2012.

Safeeq, M., Shukla, S., Arismendi, I., Grant, G. E., Lewis, S. L., and Nolin, A.: Influence of winter season climate variability on snow-precipitation ratio in the western United States, Int. J. Climatol., 36, 3175-3190, doi:10.1002/joc.4545, 2016.

Salas, J. and Obeysekera, J.: Revisiting the Concepts of Return Period and Risk for Nonstationary Hydrologic Extreme Events, J. Hydrol. Eng., 19, 554-568, doi:10.1061/(ASCE)HE.19435584.0000820, 2013.

Serreze, M. C., Clark, M. P., Armstrong, R. L., McGinnis, D. A., and Pulwarty, R. S.: Characteristics of the western United States snowpack from snowpack telemetry (SNOTEL) data, Water Resour. Res., 35, 2145-2160, doi:10.1029/1999wr900090, 1999.

Service, R. F.: As the West Goes Dry, Science, 303, 1124-1127, doi:10.1126/science.303.5661.1124, 2004.

Sproles, E. A.: Climate change impacts on mountain snowpack presented in a knowledge to action framework, $\mathrm{PhD}$ thesis, Oregon State University, Corvallis, Oregon, 192 pp., http://hdl.handle. net/1957/28640, 2012.

Sproles, E. A.: A spatial-probabilistic assessment of the extraordinarily low snowpacks of 2014 and 2015 in the Oregon Cascades, OSU Libraries, Dataset, doi:10.7267/N9V985ZN, 2017.

Sproles, E. A., Nolin, A. W., Rittger, K., and Painter, T. H.: Climate change impacts on maritime mountain snowpack in the Oregon Cascades, Hydrol. Earth Syst. Sci., 17, 2581-2597, doi:10.5194/hess-17-2581-2013, 2013.

Stewart, I. T.: Changes in snowpack and snowmelt runoff for key mountain regions, Hydrol. Process., 23, 78-94, doi:10.1002/hyp.7128, 2009.

Stewart, I. T., Cayan, D. R., and Dettinger, M. D.: Changes in Snowmelt Runoff Timing in Western North America under a 'Business as Usual' Climate Change Scenario, Climatic Change, 62, 217-232, doi:10.1023/B:CLIM.0000013702.22656.e8, 2004.
Stoelinga, M. T., Albright, M. D., and Mass, C. F.: A New Look at Snowpack Trends in the Cascade Mountains, J. Climate, 23, 2473-2491, doi:10.1175/2009JCLI2911.1, 2010.

Sturm, M., Holmgren, J., and Liston, G. E.: A Seasonal Snow Cover Classification-System for Local to Global Applications, J. Climate, 8, 1261-1283, doi:10.1175/15200442(1995)008<1261:assccs>2.0.co;2, 1995.

Tague, C. and Grant, G. E.: Groundwater dynamics mediate low-flow response to global warming in snowdominated alpine regions, Water Resour. Res., 45, W07421, doi:10.1029/2008WR007179, 2009.

Tennant, C. J., Crosby, B. T., Godsey, S. E., VanKirk, R. W., and Derryberry, D. R.: A simple framework for assessing the sensitivity of mountain watersheds to warming-driven snowpack loss, Geophys. Res. Lett., 42, 2814-2822, 2015.

United States Army Corps of Engineers: Comprehensive water supply study: An examination of current water supply issues, edited by: Hillyer, T. M., IWR Report 01-PS-1, 24 pp., 2001.

United States Army Corps of Engineers: US Army Corps - Portland District, available at: http://www.nwp.usace.army.mil/Locations/ Willamette-Valley/, last access: 16 July 2016.

United States Department of Agriculture: CarmenSmith Hydroelectric Project Area Map, available at: http://www.fs.usda.gov/detailfull/willamette/landmanagement/ resourcemanagement/?cid=stelprdb5043611\&width=full, last access: 16 July 2016.

United States Geological Survey: USGS Current Conditions for Oregon, available at: http://waterdata.usgs.gov/or/nwis/uv?, last access: 18 August 2015.

Wang, A.: Detroit Lake residents, visitors warned of toxic algae bloom, The Oregonian, 15 May 2015.

Webb, L. B., Watterson, I., Bhend, J., Whetton, P. H., and Barlow, E. W. R.: Global climate analogues for winegrowing regions in future periods: projections of temperature and precipitation, Aust. J. Grape Wine R., 19, 331-341, 2013.

Young, I. T.: Proof without prejudice: use of the KolmogorovSmirnov test for the analysis of histograms from flow systems and other sources, J. Histochem. Cytochem., 25, 935-941, 1977. 